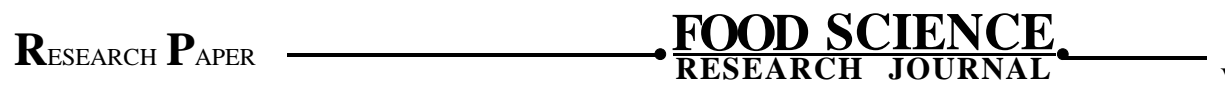

e ISSN-2230-9403 - Visit us : www.researchjournal.co.in Volume 8 | Issue 2 | October, 2017 | 266-270

DOI : 10.15740/HAS/FSRJ/8.2/266-270

\title{
Studies on exploration of orange pomace powder on physical, sensorial and nutritional quality of biscuits
}

\author{
M.A. Zaker, A.R. Sawate, S.K. Sadawarte, B.M. Patil and R.B. Kshirsagar
}

Processing of fruit and vegetable produces large quantity of waste particularly citrus processing produces waste in the form of peel, seeds and pomace which can be the major source of phytochemicals and dietary fibres. The objective of the research was to utilize the orange pomace in the form of powder in biscuits. The orange pomace powder was used in various proportion viz, $0,5,10,15$ and 20 per cent levels for incorporation in biscuits by replacing the maida. The orange pomace powder and maida were analyzed for the proximate composition. The biscuits were prepared and analyzed for its physical (diameter, thickness, and spread ratio), chemical (moisture, protein, fat, ash, fibre) and sensorial characteristics (appearance, colour, flavour, taste, texture). On the basis of overall sensory attributes biscuits prepared with 10 per cent of orange pomace powder were recorded higher acceptability as compared to other samples. The spread ratio of the biscuits also decreased as the per cent of orange pomace powder was increased with the increase in powder concentration the protein, fat content was gradually, decreasing and the dietary fibre. Orange pomace powder can be substituted upto 10 per cent in wheat flour to prepare orange pomace powder biscuits without adversely affecting overall quality attributes.

Key Words : Pomace powder, Sensorial characteristics, Quality attributes

How to cite this article : Zaker, M.A., Sawate, A.R., Sadawarte, S.K., Patil, B.M. and Kshirsagar, R.B. (2017). Studies on exploration of orange pomace powder on physical, sensorial and nutritional quality of biscuits. Food Sci. Res. J., 8(2): 266-270, DOI : 10.15740/HAS/FSRJ/8.2/266-270. 